\title{
Study on Aqueous Enzymatic Extraction Process of Common Pistache Oil
}

\author{
Feng Xuehua*, Tao Ali, Song Zurong, Gong Panpan \\ College of Pharmacy, Anhui Xinhua University,Anhui, Hefei, 230088
}

\begin{abstract}
The aqueous enzymatic method was applied to extract the common pistache oil and the optimal extraction process conditions were identified. By observing the effect of enzymatic hydrolysis time, $\mathrm{pH}$ value, temperature on aqueous enzymatic extraction process and performing the orthogonal experiment based on the single factor test, the optimal process parameters were obtained, namely, the optimal time, temperature, and $\mathrm{pH}$ value were respectively $3 \mathrm{~h}, 50^{\circ} \mathrm{C}$, and 7 with a final extraction rate of $25.38 \%$.
\end{abstract}

\section{Introduction}

Common pistache represents one of the four dominant nuts in the world and has been viewed as a precious variety among nuts thanks to its high nutritional value and pharmacological action ${ }^{[1]}$. Meanwhile, the kernel of common pistache contains ingredients such as fat, vitamin E, resveratrol, lutein, and quercetin. The bright greenish oil of common pistache is costly and classified as a high-end product, which can nourish the bowel to relieve constipation $^{[2]}$. As a new, modern oil extraction technique, the aqueous enzymatic extraction technology boasts its eco-friendliness, safety, and low energy consumption, and is capable of realizing the simultaneous production of oil and protein with few damaged be made to proteins ${ }^{[3]}$.

\section{Materials and Methods}

\subsection{Experimental Materials}

The common pistaches used in this study came from Urumchi, Xinjiang. All pistaches were dried at $40^{\circ} \mathrm{C}$ after peeled and the seedcase was removed, and then ground into powder that was sieved using a 40 mesh sifter. Subsequently, they were sealed for later use. All reagents applied in this experiment were analytical grade.

Instruments adopted included YF-118B Chinese herbal medicine grinder, DZF-6020 electro-thermostatic blast oven, RE-1002 rotary evaporator, TDL-40B high-speed centrifuge, electric-heated thermostatic water bath, and electric analytical balance.

\section{2 Experimental Methods}

\subsubsection{Aqueous Enzymatic Extraction of Common Pistache Oil}

A total of $10 \mathrm{~g}$ of dried pistache powder was weighed and put into a flask, and the powder was dissolved 1:4 with citric acid buffer solution ( $\mathrm{pH}$ value 7). After an appropriate amount of neutral proteinase was added and fully stirred, it was hydrolyzed by soaking into the thermostat water bath at a certain temperature. Afterwards, the sample was placed in the water bath at $90^{\circ} \mathrm{C}$ for $5 \mathrm{~min}$ for enzyme deactivation. A proper amount of petroleum ether was then added for oil extraction, and the acquired filtrate was centrifuged at a rate of 4000 $\mathrm{r} / \mathrm{min}$ for $15 \mathrm{~min}$ in order to collect the supernate and emulsion. The collected liquid was mixed with a certain amount of petroleum ether to be centrifuged once again $(4000 \mathrm{r} / \mathrm{min}$ ) for $10 \mathrm{~min}$, and the final common pistache oil was obtained by volatilizing the petroleum ether in the supernatant, which was weighed to calculate the oil extraction rate.

The oil extraction rate $(\%)=$ the weight of obtained oil $(\mathrm{g}) /$ the weight of common pistache powder $(\mathrm{g}) \times 100 \%$

\subsubsection{Single Factor Test}

\subsubsection{Effect of Enzymatic Hydrolysis Time on Oil Extraction Rate}

Five samples of $10-\mathrm{g}$ dried pistache powder were weighed and respectively put into the flask. All samples were dissolved 1:4 with citric acid buffer solution ( $\mathrm{pH}$ value 7), and an appropriate amount of neutral proteinase was then added and fully stirred. The flasks were soaked into the thermostat water bath at $50{ }^{\circ} \mathrm{C}$ to perform 
enzymatic hydrolysis for separately $2 \mathrm{~h}, 2.5 \mathrm{~h}, 3 \mathrm{~h}, 3.5 \mathrm{~h}$, and $4 \mathrm{~h}$. Following that, all flasks were soaked in water baths at $90^{\circ} \mathrm{C}$ for enzyme deactivation for $5 \mathrm{~min}$, and an appropriate amount of petroleum ether was added and centrifuged to extract the common pistache oil, which was weighed and recorded ${ }^{[4]}$.

\subsubsection{Effect of Enzymatic Hydrolysis $\mathrm{pH}$ Value on Oil Extraction Rate}

Five samples of 10 -g dried common pistache powder were weighed and respectively placed into the flask. All samples were dissolved with citric acid buffer solution (1:4 sample to liquid ratio) with different $\mathrm{pH}$ values of 5, 6, 7, 8, and 9 . With a proper amount of neutral proteinase having been added and fully stirred, the samples were hydrolyzed by placing them into thermostat water baths at $50^{\circ} \mathrm{C}$ for $3 \mathrm{~h}^{[5]}$. After the end of enzymatic hydrolysis, the flasks were soaked in water baths at $90^{\circ} \mathrm{C}$ for enzyme deactivation for $5 \mathrm{~min}$, and an appropriate amount of petroleum ether was added and centrifuged to extract the common pistache oil, which was weighed and recorded.

\subsubsection{Effect of Enzymatic Hydrolysis Temperature on Oil Extraction Rate}

Five samples of $10 \mathrm{~g}$ dried common pistache powder were weighed and respectively placed into the flask, and then dissolved 1:4 with citric acid buffer solution ( $\mathrm{pH} 7)$. With a proper amount of neutral proteinase having been added and fully stirred, the flasks were put into thermostat water baths for enzymatic hydrolysis for $3 \mathrm{~h}$ respectively at $40^{\circ} \mathrm{C}, 45^{\circ} \mathrm{C}, 50^{\circ} \mathrm{C}, 55^{\circ} \mathrm{C}, 60^{\circ} \mathrm{C}^{[6]}$. Following that, the flasks were immersed in water baths at $90^{\circ} \mathrm{C}$ for enzyme deactivation for $5 \mathrm{~min}$, and a proper amount of petroleum ether was added and centrifuged to extract the common pistache oil, which was weighed.

\section{Results}

\subsection{Single Factor Test}

\subsubsection{Effect of Enzymatic Hydrolysis Time on Oil Extraction Rate}

This test was conducted at a temperature of $50^{\circ} \mathrm{C}, 3 \%$ volume of enzyme, $\mathrm{pH}$ value 7 , and 1:4 sample to liquid ratio to examine the effect of different enzymatic hydrolysis time $(2 \mathrm{~h}, 2.5 \mathrm{~h}, 3 \mathrm{~h}, 3.5 \mathrm{~h}, 4 \mathrm{~h})$ on the oil extraction rate. And the corresponding results were exhibited in Figure 1.

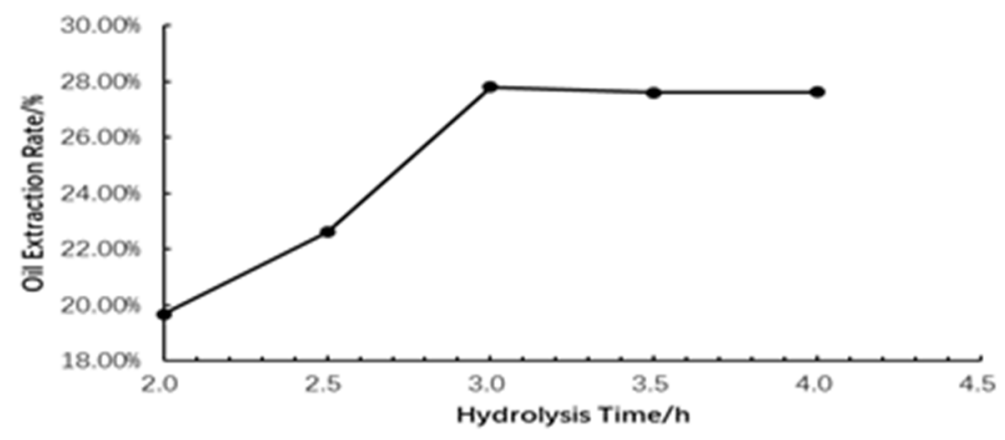

Figure 1: Effect of Enzymatic Hydrolysis Time on Oil Extraction Rate

As what can be seen from Figure 1, the oil extraction rate kept increasing before the time point $3 \mathrm{~h}$ when the enzyme can be fully reacted with the substrate, and reached the peak at $3 \mathrm{~h}$, but remained basically consistent after $3 \mathrm{~h}^{[7]}$. Therefore, it can be concluded that $3 \mathrm{~h}$ was the optimal enzymatic hydrolysis time for the sake of saving resources.

\subsubsection{Effect of Enzymatic Hydrolysis $p H$ Value on Oil Extraction Rate}

The reaction conditions were $3 \%$ volume of enzyme, $50^{\circ} \mathrm{C}, 1: 4$ sample to liquid ratio, and $3 \mathrm{~h}$ of reaction time to test the effect of different $\mathrm{pH}$ values $(\mathrm{pH} 5, \mathrm{pH} 6, \mathrm{pH}$ 7, $\mathrm{pH} \mathrm{8,} \mathrm{and} \mathrm{pH} 9$ ) on the oil extraction rate. And the results were demonstrated in Figure 2.

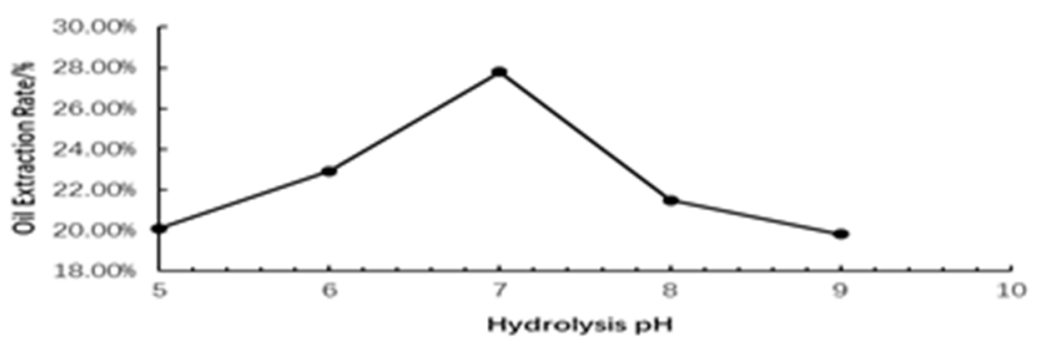

Figure 2: Effect of Enzymatic Hydrolysis pH value on Oil Extraction Rate 
As displayed in Figure 2, the oil extraction rate continued to rise before $\mathrm{pH} 7$, but slowly declined when the $\mathrm{pH}$ value was more than $7^{[8]}$. The reason lies in the fact that the dissociation of related genes on active sites of enzyme molecules would be changed when the $\mathrm{pH}$ value is deviating from the optimal value, leading to the reduced velocity of enzymatic reaction, and both peralkaline and peracid solution could cause enzyme denaturation and deactivation. Thus, it can be decided that $\mathrm{pH} 7$ serves as the optimal condition $^{[9]}$.

\subsubsection{Effect of Enzymatic Hydrolysis Temperature on Oil Extraction Rate}

The experiment was carried out under conditions: $3 \%$ volume of enzyme, 3-h reaction time, $\mathrm{pH}$ 7, 1:4 sample to liquid ratio to test the effect of different temperatures $\left(40^{\circ} \mathrm{C}, 45^{\circ} \mathrm{C}, 50^{\circ} \mathrm{C}, 55^{\circ} \mathrm{C}, 60^{\circ} \mathrm{C}\right)$ on the oil extraction rate. And the results were manifested in Figure 3.

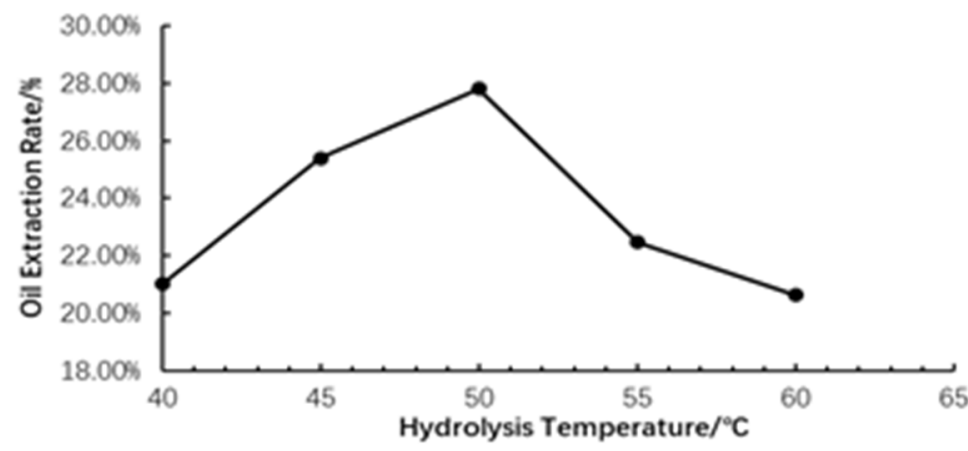

Figure 3: Effect of Enzymatic Hydrolysis Temperature on Oil Extraction Rate

As presented in Figure 3, the oil extraction rate kept climbing when the temperature was less than $50^{\circ} \mathrm{C}$, which might be due to the increased enzyme reaction activity and the enhanced movement and diffusion of oil-bearing molecules as the temperature rises, resulting in the accelerated reaction and raised oil extraction rate ${ }^{[10]}$. Afterwards, the oil extraction rate reached the peak at $50^{\circ} \mathrm{C}$, but gradually decreased when the temperature was more than $50^{\circ} \mathrm{C}$, which might be owing to the deactivated enzyme under too high temperature. Thence, $50^{\circ} \mathrm{C}$ is deemed as the optimal temperature for enzymatic hydrolysis ${ }^{[11]}$.

Table 1 Factors and Levels

\subsection{Orthogonal Experiment}

\subsubsection{Experimental Design and Results}

The orthogonal experiment of aqueous enzymatic extraction of common pistache oil was carried out on the basis of single factor test results, and the factor levels were presented in Table 1, the experimental design and results were exhibited in Table 2, and the variance analysis was shown in Table 3.

\begin{tabular}{cccc}
\hline & & Factors & \\
Levels & Hydrolysis Time $/ \mathrm{h}$ & Hydrolysis & Hydrolysis $\mathrm{pH}$ \\
& $\mathrm{A}$ & Temperature $/{ }^{\circ} \mathrm{C}$ & $\mathrm{C}$ \\
\hline 1 & 2 & 40 & 5 \\
2 & 3 & 50 & 7 \\
3 & 4 & 60 & 9 \\
\hline
\end{tabular}

Table 2 Results and Analysis

\begin{tabular}{ccccc}
\hline NO. & A & B & C & $\begin{array}{c}\text { Oil Extraction } \\
\text { Rate } / \%\end{array}$ \\
\hline 1 & 1 & 1 & 1 & 19.86 \\
2 & 1 & 2 & 2 & 23.69 \\
3 & 1 & 3 & 3 & 20.04 \\
4 & 2 & 1 & 2 & 25.54 \\
5 & 2 & 2 & 3 & 25.13 \\
6 & 2 & 3 & 1 & 22.84 \\
7 & 3 & 1 & 3 & 22.81 \\
8 & 3 & 2 & 1 & 25.35 \\
9 & 3 & 3 & 2 & 25.47 \\
$\mathrm{~K}_{1}$ & 21.197 & 22.737 & 22.683 & \\
$\mathrm{~K}_{2}$ & 24.543 & 24.723 & 22.660 &
\end{tabular}




\begin{tabular}{cccccc}
$\mathrm{K}_{3}$ & 24.503 & 22.783 & 24.900 & \\
$\mathrm{R}$ & 3.346 & 1.986 & 2.240 & \\
\multicolumn{5}{c}{ Table 3 Variance Analysis } \\
\hline Factors & $\mathrm{SS}$ & Freedom & Variance & F & Significance \\
\hline Hydrolysis Time & 22.136 & 2 & 49.744 & 19.000 & $*$ \\
Hydrolysis & 7.713 & 2 & 17.333 & 19.000 & \\
$\begin{array}{c}\text { Temperature } \\
\text { Hydrolysis pH } \\
\text { Error }\end{array}$ & $\begin{array}{c}\text { 9.932 } \\
0.45\end{array}$ & 2 & 22.319 & 19.000 & $*$ \\
\hline
\end{tabular}

According to Table 2, it can be concluded that the impact of these three parameters on the oil extraction rate was successively A $>\mathrm{C}>\mathrm{B}$, namely, enzymatic hydrolysis time $>$ enzymatic hydrolysis $\mathrm{pH}$ value $>$ enzymatic hydrolysis temperature. And the optimal combination for aqueous enzymatic extraction of oil turned out to be $\mathrm{A}_{2} \mathrm{~B}_{2}$ $\mathrm{C}_{3}$, in other words, $3 \mathrm{~h}$ of enzymatic hydrolysis time, $50^{\circ} \mathrm{C}$ of temperature, and $\mathrm{pH}$ value 9 , under which the common pistache oil extraction rate reached the highest level. In accordance with Table 3 , enzymatic hydrolysis time and $\mathrm{pH}$ value were significantly related to the oil extraction rate, but the enzymatic hydrolysis temperature failed to produce a significant influence on the oil extraction rate.

\section{Conclusion}

In this paper, the process conditions of aqueous enzymatic extraction of pistache oil were investigated by taking the common pistaches from Xinjiang as raw materials, and the orthogonal experiment was adopted to study its influencing parameters, i.e., the enzymatic hydrolysis time, temperature, and $\mathrm{pH}$ value. And the best process parameters, which can produce the highest oil extraction rate, were eventually obtained, namely, $3 \mathrm{~h}$ of time, $50^{\circ} \mathrm{C}$ of temperature, and $\mathrm{pH}$ value 9 , generating a final oil extraction rate of $25.38 \%$. The reason why the final oil extraction rate is relatively low might lie in the insufficient grinding, inadequate stirring speed that failed to reach the purpose of demulsification, deviation caused when collecting the oil, as well as other inevitable losses during the experiment ${ }^{[12]}$. Limitations of this study include the selection of enzymes, comparison of sample to liquid ratio, volume of enzyme, and the development and application of proteins and other substances in common pistaches ${ }^{[13]}$.

\section{Fund program}

Natural Science Research F oundation of the Department of Education of Anhui Prov ince (No.KJ2020A0789) ;Anhui provincial-level quality engineering project: (2020jyxm0790 2020zyrc077,2020zyrc081,2019jxjj45);school-level grassroots teaching and research office demonstration project of Anhui Xinhua University (2019jyssfx02) ; Research project of Anhui Xinhua University (kytd201908).

\section{References}

1. Pei X. Brief Analysis of Cultivation Techniques and Management Measures of Common Pistaches[J]. Serves of Agricultural Technology, 2015,32(08):3738.

2. Zheng Z, Sun W. Study on Food Safety and Nutritional Value of Nuts[J]. Farm Products Processing, 2018(09):20-23.

3. Tong T. Preventive Effect of Common Pistache Against Gestational Diabetes Mellitus[J]. China Fruit News, 2018,35(01):49-55.

4. Liu H, Ge S. Prevention and Treatment Effect of Pistachio in Chronic Metabolic Diseases[J]. Food and Nutrition in China, 2016,22(10):80-84.

5. Wang Q, Gao J, Tian W. Investigation on the Status of the Contamination of Pistachio Mildew on the Market[J]. Modern Food, 2018(05):17-18+21.

6. Ling B. Study on the Radiofrequency Insecticidal Technology and its Comprehensive Utilization in Common Pistache after Harvest[D]. Northwest Agriculture \& Forestry University, 2016.

7. Sun L. Study on Process of Aqueous Enzymatic Method in Extracting Pricklyash Seed Oil [D]. Hebei University of Engineering, 2017.

8. Qin Y. Study on Aqueous Enzymatic Extraction and Property of Cornus Walteri Oil[J]. Shandong Agricultural University, 2018.

9. Yan L. Study on Extraction and Property of Perilla Frutescens Oil[J]. Shaanxi University of Science and Technology, 2018.

10. Wuri Gumala. Study on Extraction Process of Prunus Mongolica Maxim Oil[J]. Inner Mongolia Normal University, 2017.

11. Chen Y, Zheng K, He J, et al. Composition of fatty acids of several selected commercial nut products[J]. Food Science and Technology, 2015,40(01):191-195.

12. Xiang J. Study on Enzymatic Hydrolysis Technological Parameters Optimization of Aqueous Enzymatic Extraction of Camellia Oleosa Seed Oil[D]. Hunan Agricultural University, 2015.

13. Xu D. Study on Aqueous Enzymatic Extraction of Acer Truncatum Bunge Kernel Oil[D]. Northwest 
Agriculture \& Forestry University, 2016. 